\title{
PENGARUH DISIPLIN DAN MOTIVASI TERHADAP KINERJA PEGAWAI BIDANG TATA RUANG DAN PERMUKIMAN PADA DINAS CIPTA KARYA KABUPATEN KARAWANG
}

\author{
Sungkono \\ sungkono@ubpkarawang.ac.id
}

\begin{abstract}
ABSTRAK
Kinerja adalah hasil kerja yang dapat dicapai oleh seseorang atau sekelompok orang dalam suatu organisasi, sesuaidengan wewenang dan tanggung jawab masing-masing dalam rangka upaya mencapai tujuanorganisasi yang bersangkutan secara legal, tidak melanggar hukum dan sesuai dengan moralmaupun etika. Jadi kinerja merupakan hal yang penting bagi perusahaan atau organisasi sertadari pihak pegawai itu sendiri. Kinerja pegawai dipengaruhi oleh beberapa faktor baik yang berhubungan dengan tenaga kerja itu sendiri maupun yang yang berhubungan dengan lingkungan perusahaan atau organisasi

Masalah pokok dalam penelitian ini adalah belum optimalnya kinerja aparatur pada Dinas Cipta Karya bidang Tata ruang dan pemukiman pemerintah Kabupaten Karawang yang dipengaruhi oleh disiplin dan motivasi kerja aparatur. Oleh karenanya, perlu dilakukan penelitian lebih lanjut yang dilaksanakan pada bulan September 2015 sampai dengan Maret 2016 dengan tujuan untuk mengetahui seberapa besar pengaruh disiplin kerja dan motivasi kerja, baik secara parsial maupun simultan terhadap kinerja aparatur Dinas Cipta Karya bidang Tata ruang dan pemukiman Pemerintah Kabupaten Karawang.

Desain penelitian ini adalah explanatory survey, yaitu berupaya menganalisis pengaruh yang terjadi antara variabel disiplin kerja $\left(\mathrm{X}_{1}\right)$ dan variabel motivasi kerja $\left(\mathrm{X}_{2}\right)$ dengan kinerja (Y). Paradigma penelitian adalah kuantitatif dan metode yang digunakan adalah penelitian deskriptif. Karena populasi penelitian hanya berjumlah 90 orang, maka sampel yang digunakan adalah total sampling (sampel populasi). Pengumpulan data primer menggunakan kuisioner, ditambah observasi dan wawancara. Sedangkan data sekunder melalui studi dokumentasi dan data terkait. Teknik pengolahan dan analisis data menggunakan teknik korelasi Product Moment dan regresi linear berganda, dengan bantuan software komputer, SPSS versi 23,0.
\end{abstract}

Keyword : Disiplin dan Motivasi berpengaruh pada Kinerja

\section{PENDAHULUAN}

1. Jurnal Manajemn \& Bisnis Kreatif 
Ketentuan hukum disiplin PNS, diatur dengan Peraturan Pemerintah No.53 Tahun 2010 tentang Disiplin PNS. Secara prinsip kewenangan dan tanggung jawab penjatuhan hukum disiplin setiap PNS berada pada atasan atau pimpinan masing-masing secara berjenjang. Setiap atasan langsung PNS adalah pejabat yang berwenang menjatuhkan hukum disiplin, jika tidak dilakukan maka atasan pejabat berwenang akan menjatuhkan hukum disiplin kepada PNS secara berjenjang, mulai ringan, sedang sampai berat, mulai dari teguran lisan, penundaan kenaikan pangkat sampai pemecatan.

Permasalahan disiplin kerja dalam penelitian ini, pada pegawai Dinas Cipta Karya Kabupaten Karawang tentang kehadiran dan ketepatan waktu kerja, belum ada kegiatan yang mendukung untuk memacu prestasi kerja pegawai dan kurangnya kesadaran kolektif untuk meningkatkan disiplin kerja .

Data empirik kedisiplinan pada dinas Cipta Karya Kabupaten Karawang adalah :

Tabel 1.1

Penilaian Disiplin Kerja Pegawai Dinas Cipta Karya Kabupaten Karawang

Prosentase Kualitas Kehadiran pegawai Dinas Cipta Karya Kabupaten

\begin{tabular}{c|c|c|c|c|c|c}
\multicolumn{7}{|c}{ Karawang } \\
\hline No & Uraian & $\mathbf{2 0 1 0}$ & $\mathbf{2 0 1 1}$ & $\mathbf{2 0 1 2}$ & $\mathbf{2 0 1 3}$ & $\mathbf{2 0 1 4}$ \\
\hline 1. & Penilaian disiplin & $85 \%$ & $87 \%$ & $87 \%$ & $90 \%$ & $90 \%$ \\
\hline 2. & Pria & $65 \%$ & $60 \%$ & $52 \%$ & $49 \%$ & $44 \%$ \\
\hline 3 & Wanita & $35 \%$ & $40 \%$ & $48 \%$ & $51 \%$ & $46 \%$
\end{tabular}

Sumber : Badan Kepegawaian Daerah (BKD) Kabupaten Karawang, 2016

Permasalahan motivasi kerja yang sering terjadi pada belakangan ini adalah tidak selalu motivasi itu disiratkan dalam teori kebutuhan dapat menjamin sepenuhnya terhadap timbulnya motivasi seseorang. Karena, selain pentingnya pemenuhan kebutuhan, seorang pegawai membutuhkan adanya pengakuan tentang keberadaannya dalam organisasi tersebut.

Data empirik tentang motivasi pegawai Dinas Cipta Karya Kabupaten Karawang adalah :

Tabel 1.2

Ketidakhadiran Pegawai Dinas Cipta Karya Kabupaten Karawang

\begin{tabular}{c|c|c|c|c|c|c}
\multicolumn{7}{c}{ Prosentase Ketidakhadiran Pegawai Dinas Cipta Karya } \\
Kabupaten Karawang \\
\hline No & Uraian & $\mathbf{2 0 1 0}$ & $\mathbf{2 0 1 1}$ & $\mathbf{2 0 1 2}$ & $\mathbf{2 0 1 3}$ & $\mathbf{2 0 1 4}$ \\
\hline 1 & Mangkir & $5 \%$ & $10 \%$ & $12 \%$ & $14 \%$ & $15 \%$ \\
\hline 2 & Ijin Resmi & $3 \%$ & $5 \%$ & $10 \%$ & $11 \%$ & $13 \%$ \\
\hline 3 & Sakit & $2 \%$ & $4 \%$ & $7 \%$ & $10 \%$ & $12 \%$
\end{tabular}

Sumber : Badan Kepegawaian Daerah (BKD) Kabupaten Karawang, 2016

Permasalahan kinerja pada Dinas Cipta Karya Kabupaten Karawang baik secara internal maupun eksternal, adalah bagaimana implementasi sistem yang digunakan untuk mengukur kinerja pegawai, seperti : masuk kerja tidak tepat waktu, kurangnya pengawasan yang melekat, kurangnya kesadaran pegawai terhadap TUPOKSI ( tugas pokok dan fungsi ), fasilitas kerja yang kurang lengkap, tidak adanya penghargaan terhadap pegawai yang berprestasi, tingkat pendidikan pegawai masih standar.

Data empirik tentang kinerja pegawai pada Dinas Cipta Karya Kabupaten Karawang adalah :

2.

Jurnal Manajemn \& Bisnis Kreatif 
Tabel 1.3

Kinerja Pegawai Bidang Tata Ruang dan Pemukiman Dinas Cipta Karya Kabupaten Karawang

\begin{tabular}{c|c|c}
\multicolumn{3}{c}{ Kinerja Pegawai Dinas Cipta Karya Kabupaten Karawang } \\
\hline No. & Tahun & Capaian \\
\hline 1. & 2010 & $80,5 \%$ \\
\hline 2. & 2011 & $80,8 \%$ \\
\hline 3 & 2012 & $90 \%$ \\
\hline 4 & 2013 & $90,5 \%$ \\
\hline 5 & 2014 & $90,5 \%$
\end{tabular}

\section{RUMUSAN MASALAH}

Problem Statement: “ Kinerja Pegawai di Bidang Tata Ruang Dinas Cipta Karya Kabupaten Karawang, belum tercapai disebabkan oleh Disiplin Kerja dan Motivasi para pegawai masih rendah. Adapun Problem Question dalam penelitian ini adalah : "Seberapa besar pengaruh Disiplin Kerja dan Motivasi terhadap Kinerja Pegawai pada Bidang Tata Ruang Dinas Cipta Karya Kabupaten Karawang “.

Berdasarkan tersebut di atas, maka rumusan permasalahannya adalah sebagai berikut :

1. Seberapa besar korelasi atau hubungan antara Disiplin dengan Motivasi kerja Pegawai Bidang Tata Ruang dan Pemukiman pada Dinas Cipta Karya Kabupaten Karawang.

2. Seberapa besar koefisien determinasi atau pengaruh parsial Disiplin dan Motivasi terhadap Kinerja Pegawai Bidang Tata Ruang dan Pemukiman pada Dinas Cipta Karya Kabupaten Karawang.

3. Seberapa besar koefisien determinasi atau pengaruh simultan Disiplin dan Motivasi terhadap Kinerja Pegawai Bidang Tata Ruang dan Pemukiman pada Dinas Cipta Karya Kabupaten Karawang.

\section{TUJUAN PENELITIAN}

Adapun tujuan dari penelitian ini adalah :

1. Untuk mengetahui, menganalisis, dan menjelaskan hubungan Disiplin dengan Motivasi Pegawai Bidang Tata Ruang dan Pemukiman pada Dinas Cipta Karya Kabupaten Karawang.

2. Untuk mengetahui, menganalisis, dan menjelaskan pengaruh parsial Disiplin dan Motivasi terhadap Kinerja Pegawai Bidang Tata Ruang dan Pemukiman Dinas Cipta Karya Kabupaten Karawang.

3. Untuk mengetahui, menganalisis, dan menjelaskan pengaruh simultan Disiplin dan Motivasi terhadap Kinerja Pegawai Bidang Tata Ruang dan Pemukiman Dinas Cipta Karya Karawang.

\section{LANDASAN TEORI}

\section{A. Penelitian Terdahulu yang Relevan}

Penelitian terdahulu yang relevan adalah :

Kaliri, 1103506062 ; 2008. Pascasarjana Universitas Negeri Semarang. " Pengaruh Disiplin dan Motivasi terhadap Kinerja Guru SMA Negeri di Kabupaten Pemalang”. Teknik proportional random sampling, analisis menggunakan regresi. Hasil : (1) Pengaruh disiplin

3. 
terhadap kinerja guru SMA Negeri Kabupaten Pemalang 8,3\% ; (2) Pengaruh motivasi terhadap kinerja Guru SMA Negeri di Kabupaten Pemalang 14,3\%; (3) Pengaruh disiplin dan motivasi kerja secara bersama-sama terhadap kinerja guru SMA Negeri di Kabupaten Pemalang 21,5\%. Sisanya 78,5\% ditentukan factor lain di luar penelitian ini.

Annisa Pratiwi, 12010110120109 ; 2014. Fakultas / Jurusan : Ekonomika dan Bisnis / Manajemen-Undip. “ Pengaruh Motivasi dan Disiplin Kerja Terhadap Kinerja Karyawan ( Studi Pada Karyawan Kantor PT Telekomunikasi Indonesia Tbk. Wilayah Telkom Pekalongan )". Sampel dengan metode Convenience sampling. Analisis dengan regresi berganda, signifikansi 0,05 Hasil perhitungan diperoleh persamaan regresi : $\mathrm{Y}=0,491 \mathrm{X} 1+$ 0,194 X2. Hasil : pengaruh motivasi terhadap kinerja karyawan, tingkat signifikan 0,002 < 0,05 . Hipotesis menyatakan : motivasi kerja memiliki pengaruh terhadap kinerja karyawan dapat diterima. Tidak terdapat pengaruh signifikan antara disiplin terhadap kinerja, tingkat signifikan 0,199 >0,05. Pengaruh variabel motivasi dan disiplin kerja secara simultan terhadap kinerja karyawan PT Telekomunikasi Indonesia Tbk. Witel Pekalongan, tingkat signifikansi 0,000 .

Siti Masrifatul Laili, 10810201315; 2014. Jurusan Manajemen Fakultas Ekonomi Universitas Jember. " Pengaruh Disiplin Kerja dan Motivasi Terhadap Kinerja PNS Pemerintah Kabupaten Situbondo “. Penelitian bersifat explanatory research. Pengumpulan data melalui kuesioner. Analisis regresi linier berganda; variabel bebas disiplin kerja dan motivasi, dan variabel terikat kinerja. Hasil : disiplin kerja tidak berpengaruh signifikan terhadap kinerja pegawai dengan nilai pengaruh 0,506 . Pengaruh motivasi signifikan terhadap kinerja pegawai dengan nilai sebesar 0,00 . Uji F disiplin dan motivasi berpengaruh signifikan terhadap kinerja PNS Pemkab Situbondo dengan nilai signifikansi 0,00.

\section{B. Applied Theory}

\section{Pengertian Disiplin}

Marwansyah ( $2012: 410$ ), mengatakan bahwa : disiplin adalah tindakan manajemen yang mendorong terciptanya ketaatan pada standar-standar organisasi. Sedangkan disiplin pegawai adalah sarana yang digunakan oleh manajer untuk mengkomunikasikan kepada karyawan bahwa ia harus mengubah perilakunya.

Sedarmayanti (2011 : 381 ), kewajiban yang harus diperhatikan PNS antara lain :

a. Mempertahankan ideologi negara yaitu Pancasila dan Undang-Undang Dasar 1945.

b. Menunjukkan kesetiaan terhadap bangsa, negara, dan Pemerintah Republik Indonesia.

c. Mengutamakan kepentingan negara di atas kepentingan golongan/diri sendiri.

d. Melaksanakan tugas dan tanggung jawab sebaik-baiknya menurut tugasnya masingmasing.

e. Menggunakan barang-barang milik negara hanya untuk kepentingan pelaksanaan tugas.

f. Mentaati semua peraturan perundang-undangan yang berlaku.

\section{Pengertian Motivasi}

Suwatno, at al. (2011 : 172), mengatakan bahwa : " motivasi yang ada dalam diri seseorang merupakan pendorong yang akan mewujudkan suatu perilaku guna mencapai tujuan kepuasan dirinya. Orang mau bekerja untuk memenuhi kebutuhan, baik kebutuhan yang disadari (conscious needs) maupun kebutuhan/keinginan yang tidak disadari

4.

Jurnal Manajemn \& Bisnis Kreatif 
(unconscious needs ); demikian juga orang mau bekerja untuk mendapatkan kebutuhan fisik dan mental".

Edy Sutrisno (2009:111), mengatakan: faktor-faktor yang mempengaruhi motivasi :

a. Faktor Intern :

1) Keinginan untuk hidup, meliputi : memperoleh kompensasi memadai; memperoleh pekerjaan; memperoleh kondisi kerja yang aman dan nyaman.

2) Keinginan untuk memiliki : hal ini banyak dialami dalam kehidupan, bahwa keinginan yang keras untuk dapat memiliki itu dapat mendorong orang mau bekerja.

3) Keinginan memperoleh penghargaan ( diakui, dihormati orang lain, status sosial.

4) Keinginan pengakuan : penghargaan prestasi yang dicapai dalam melaksanakan tugasnya; hubungan kerja yang harmonis; sikap pimpinan adil dan bijaksana; tempat bekerja yang dihargai.

5) Keinginan berkuasa : kadang-kadang keinginan berkuasa dipenuhi dengan cara yang tidak terpuji.

\section{b. Faktor ekstern}

1) Kondisi lingkungan kerja : keseluruhan sarana dan prasarana kerja yang ada disekitar karyawan sedang melakukan pekerjaan dapat mempengaruhi pelaksanaan pekerjaan.

2) Kompensasi memadai : memadai merupakan alat motivasi yang paling ampuh bagi organisasi untuk mendorong karyawan bekerja dengan baik.

3) Adanya jaminan pekerjaan : setiap orang pada umumnya akan bekerja keras apabila yang bersangkutan merasa adanya jaminan karier yang jelas.

4) Status dan tanggung jawab : pegawai bukan hanya mengharapkan kompensasi semata, tetapi juga berharap akan dapat kesempatan menduduki jabatan dalam organisasi.

5) Peraturan yang fleksibel : mengatur hubungan kerja antara karyawan dengan perusahaan, termasuk hak dan kewajiban, kompensasi, promosi, mutasi dan sebagainya.

\section{Pengertian Kinerja}

Lawler (1991) dalam Khaerul Umam ( 2010 :199 ), mengatakan : “ Prestasi kerja adalah suatu hasil yang dicapai oleh karyawan dalam mengerjakan tugas atau pekerjaannya secara efisien dan efektif. Prestasi kerja adalah kesuksesan kerja yang peroleh seseorang dari hasil yang bersangkutan ".

Anwar Prabu Mangkunegara (2007:13), mengatakan bahwa factor-faktor yang dapat memepengaruhi terhadap pencapaian kinerja terdiri mdari : kemampuan (ablity) dan motivasi (motivation), sesuai rumusan Keith Davis, $(1964 ; 484)$ : Human Performance $=$ Ability + Motivation $;$ Motivation $=$ Attitude + Situtation $;$ dan Ability $=$ Knowladge + Skill .

\section{KERANGKA PEMIKIRAN}

Kerangka pemikiran teoritis pada penelitian ini adalah sebagai berikut :

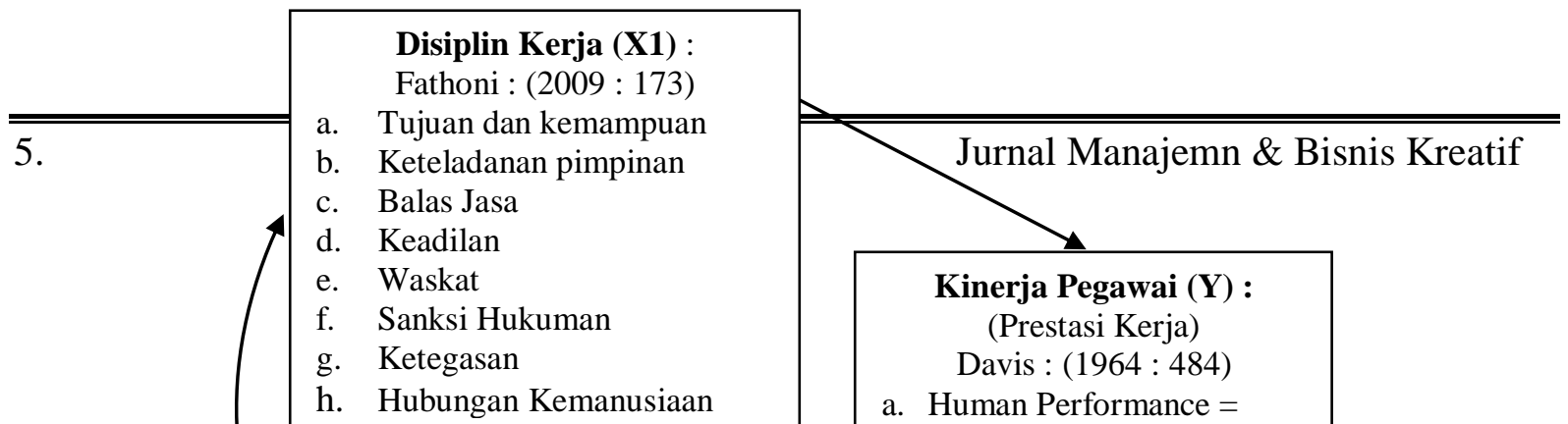




\section{VARIABEL PENELITIAN}

\section{a. Variabel Disiplin $\left(\mathbf{X}_{\mathbf{1}}\right)$}

Variable disiplin merupakan sebuah objek dasar yang di teliti karena berkenaan pengaruh sebab - akibat terhadap tujuan terhadap peningkatan kinerja aparatur pemerintah Kabupaten Karawang Disiplin adalah kesadaran dan kesediaan pegawai mentaati semua peraturan dan tata tertib organisasi. Disiplin mempunyai indicator : tujuan dan kemampuan; keteladanan pimpinan; balas jasa; keadilan; waskat; sanksi hukum; ketegasan; hubungan kemanusiaan.

\section{b. Variabel Motivasi $\left(\mathbf{X}_{2}\right)$}

Variable ini bagian dari sub objek lain yang membentuk karakter terhadap sifat kinerja, variabel motivasi berpengaruh positif terhadap peningkatan kinerja pegawai.

Motivasi kerja adalah dorongan pegawai untuk melakukan tindakan mencapai hal yang spesifik sesuai dengan tujuan individu. Indikator Motivasi terdiri : Upah adil dan layak; Kesempatan untuk maju; Pengakuan sebagai individu; Keamanan kerja; Tempat kerja yang baik; Penerimaan kelompok; Perlakuan wajar, dan; Pengakuan atas prestasi.

\section{c. Variabel Kinerja pegawai ( $Y$ )}

Variable ini sebagai variable terikat yang menjadi pusat hasil analisis pada penelitian ini, karena berdasarkan kondisi yang terjadi saat ini faktor kinerja menjadi sebuah masalah dalam organisasi perangkat daerah (OPD) Dinas Cipta Karya Kabupaten Karawang.

Kinerja pegawai adalah hasil kerja yang dihasilkan oleh seseorang atau perilaku nyata yang ditampilkan sesuai dengan peranya dalam organisasi. Indicator kinerja pegawai

6. 
terdiri dari : Human Performance $=($ Ability + Motivation $) ;$ Motivation $=($ Atitude + Situation $) ;$ Ability $=($ Knowledge + Skill/Dicipline $)$.

d. Operasionalisasi Variabel

Adapun operasionalisi variabel yang digunakan dalam penelitian ini, dapat ditabulasikan sebagai berikut :

Tabel. 1

Operasionalisasi Variabel Disiplin (Fathoni,2009:173 )

\begin{tabular}{l|l}
\multicolumn{1}{c|}{ Dimensi } & \multicolumn{1}{c}{ Indikator } \\
\hline Tujuan dan kemampuan & $\begin{array}{l}\text { Tujuan pekerjaan; Kemampuan } \\
\text { kerja. }\end{array}$ \\
\hline Keteladanan pimpinan & Sikap; Perbuatan. \\
\hline Balas Jasa & Kompensasi; Kesejahteraan. \\
\hline Keadilan & $\begin{array}{l}\text { Perlakuan sama; Kesamaan } \\
\text { hokum. }\end{array}$ \\
\hline Pengawasan melekat & $\begin{array}{l}\text { Arahan pimpinan; Perhatian } \\
\text { atasan. }\end{array}$ \\
\hline Sanksi Hukuman & Sanksi positif; Sanksi negatif \\
\hline Ketegasan & Konsistensi sanksi \\
\hline Hubungan Kemanusiaan & Vertikal; Horizontal.
\end{tabular}

Sumber : Fathoni (2009:173)

Tabel. 2

Operasionalisasi Variabel Motivasi

\begin{tabular}{l|l}
\multicolumn{1}{c|}{ Dimensi } & \multicolumn{1}{c}{ Indikator } \\
\hline Upah adil dan layak & Nyaman; Kesejahteraan \\
\hline Kesempatan maju & $\begin{array}{l}\text { Pengembanga Karir; Kepuasan } \\
\text { kerja. }\end{array}$ \\
\hline Pengakuan individu & Pengakuan; Keterlibatan. \\
\hline Keamanan kerja & $\begin{array}{l}\text { Keselamatan kerja; Kesehatan } \\
\text { kerja. }\end{array}$ \\
\hline Tempat kerja baik & Sarana; Prasarana; \\
\hline Penerimaan kelompok & Strata structural; Strata fungsional. \\
\hline Perlakuan yang wajar & Dihargai \\
\hline Pengakuan prestasi & Reward; Punishment.
\end{tabular}

Sumber : CS. George dalam Hasibuan, (2008 : 163)

Tabel. 3

Operasionalisasi Variabel Kinerja 


\begin{tabular}{l|l}
$\begin{array}{l}\text { Human Performance } \\
\text { (Ability + Motivation) }\end{array}$ & $\begin{array}{l}\text { Kualitas ; Kuantitas; Tepat } \\
\text { sasaran } \\
\text { Tepat waktu; Tepat guna }\end{array}$ \\
\hline $\begin{array}{l}\text { Motivation (Atitude + } \\
\text { Situation) }\end{array}$ & $\begin{array}{l}\text { Semangat; Beriteraksi } \\
\text {;Kerjasama } \\
\text { Beradaptasi; Pemecahan masalah }\end{array}$ \\
\hline $\begin{array}{l}\text { Ability (Knowledge + } \\
\text { Skill/Dicipline) }\end{array}$ & $\begin{array}{l}\text { Kehadiran; Pengetahuan; } \\
\text { Ketrampilan; Sikap moral; } \\
\text { Disiplin yang tinggi }\end{array}$ \\
\hline
\end{tabular}

Sumber : Keith Davis, (1964 : 484)

\section{MODEL YANG DIGUNAKAN}

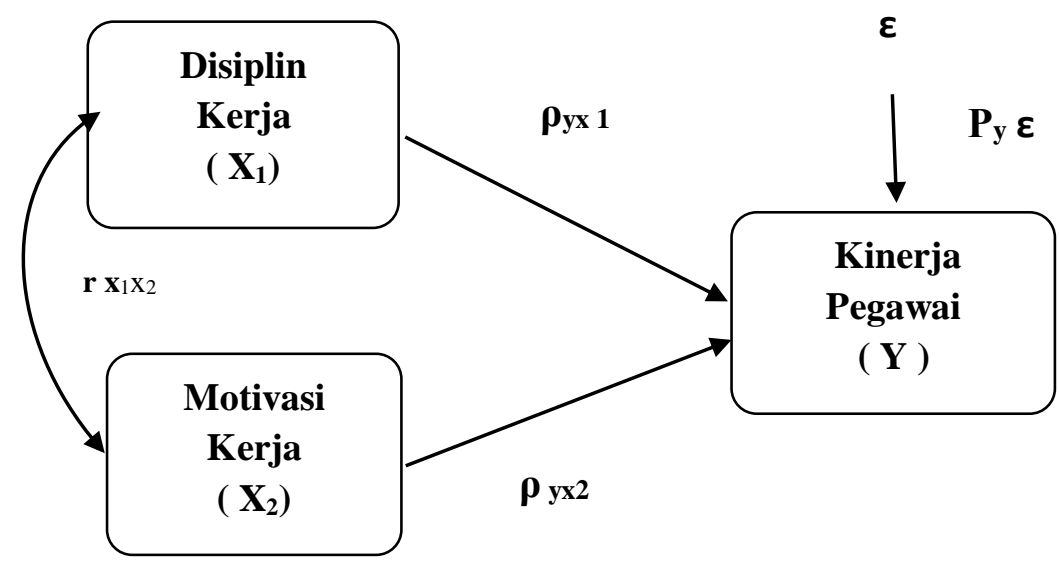

Gambar . 2

Model Path Analysis

Sumber : Penulis, 2016

\section{TEKNIK PENGUMPULAN DATA}

\section{Populasi Penelitian}

Populasi dalam penelitian ini adalah seluruh pegawai Bidang Tata Ruang dan Pemukiman Dinas Cipta Karya Kabupaten Karawang, sebanyak 50 orang, terdiri dari :

Tabel. 4

Ukuran Populasi

\begin{tabular}{l|c}
\multicolumn{3}{c}{ Jumlah Pegawai } \\
\hline \multicolumn{3}{c|}{ Status } & Jumlah \\
\hline $\begin{array}{l}\text { Kepala Bidang Tata Ruang \& } \\
\text { Pemukinan }\end{array}$ & 1 \\
\hline Kepala Seksi & 3
\end{tabular}

8. 


\begin{tabular}{l|c} 
Pegawai Funsional/PNS & 21 \\
\hline Pegawai Funsional/Non PNS & 25 \\
\hline Total Sumber : Penulis ( 2016$)$
\end{tabular}

\section{Teknik Penarikan Sampel}

Teknik sampling dengan prorportionate stratified random sampling, ditabulasikan :

Tabel .5

Jumlah Strata Sampel

\begin{tabular}{l|c|c}
\multicolumn{3}{c}{ Jumlah Pegawai } \\
\hline \multicolumn{1}{c|}{ Status } & Jumlah & Sampel \\
\hline Kepala Bidang & 1 & $1 / 50 \times 44=1$ \\
\hline Kepala Seksi & 3 & $3 / 50 \times 44=3$ \\
\hline Pegawai Funsional/PNS & 21 & $21 / 50 \times 44=$ \\
& & 18 \\
\hline $\begin{array}{l}\text { Pegawai Funsional/Non } \\
\text { PNS }\end{array}$ & 25 & $\begin{array}{c}25 / 50 \times 44= \\
\text { Total Sumber : Penulis (2016) }\end{array}$
\end{tabular}

\section{TEKNIK ANALISIS DATA}

\section{Analisis Deskriptif :}

Analisis deskriptif dari hasil pengukuran dengan instrumen skala likert dengan menggunakan formulasi sebagai berikut :

$$
\mathrm{RS}=\frac{n(m-1)}{M}
$$

Skala terendah $=$ Skor terendah $\times$ Jumlah Sampel $(\mathrm{n})=1 \times 44=44$

Skala tertinggi $=$ Skor tertinggi $\mathrm{x}$ Jumlah Sampel $=5 \times 44=220$

Sehingga rentang skalanya adalah :

$$
R S=\frac{44(5-1)}{5}=35,2
$$

Pengklasifikasian persentase untuk skor jawaban dari hasil pernyataan yang diajukan kepada responden adalah :

Tabel . 6

\begin{tabular}{|c|c|c|c|c|}
\hline Skal & Rentang Skala & \multicolumn{3}{|c|}{ Deskripsi Skor } \\
\hline $\begin{array}{l}\text { a } \\
\text { Skor }\end{array}$ & & Disiplin & Motivasi & Kinerja \\
\hline 1 & $44-79,2$ & $\begin{array}{ll}\text { Sangat } & \text { Tidak } \\
\text { Setuju } & \end{array}$ & $\begin{array}{ll}\text { Sangat } & \text { Tidak } \\
\text { Setuju } & \end{array}$ & $\begin{array}{ll}\text { Sangat } & \text { Tidak } \\
\text { Setuju } & \end{array}$ \\
\hline
\end{tabular}

Analisis Rentang Skala

9.

Jurnal Manajemn \& Bisnis Kreatif 


\begin{tabular}{c|c|l|l|l}
2 & $79,3-114,4$ & Tidak Setuju & Tidak Setuju & Tidak Setuju \\
\hline 3 & $114,5-149,6$ & Cukup Setuju & Cukup Setuju & Cukup Setuju \\
\hline 4 & $149,7-184,8$ & Setuju & Setuju & Setuju \\
\hline 5 & $184,9-220$ & Sangat Setuju & Sangat Setuju & Sangat Setuju
\end{tabular}

Sumber : Hasil Olahan ( 2016 )

Rentang skala untuk kondisi disiplin, motivasi dan kinerja pegawai Bidang Tata Ruang dan Pemukiman Dinas Cipta Karya Kabupaten Karawang, yang dapat dituangkan dalam bentuk gambar Bar Scale sebagai berikut :

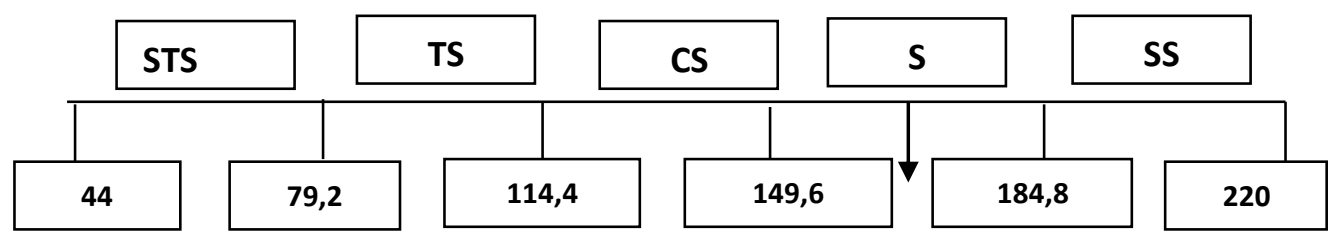

Gambar . 3 : Bar Scale

Sumber : Data Diolah ( 2016 )

Pada bar Skala tersebut, dapat diasumsikan, apabila total skor ideal ( kriterium ) untuk seluruh item adalah $=220$ ( apabila semuanya menjawab Sangat Setuju ). Apabila skor total $=$ 160 , maka tingkat persetujuan responden $=(160: 220) \times 100 \%=73 \%$, artinya bahwa $73 \%$ responden menyatakan setuju.

\section{Analisis Verifikatif :}

Analisis verifikatif adalah perhitungan matematis, yang skala pengukuran data minimal berskala interval. Jika data berskala ordinal, ditransformasi menjadi skala interval dengan uji Method of Successive Interval.

Analisis data yang telah dikonversi, diolah menggunakan Path Analisis, yang dikembangkan pertama tahun 1920-an oleh ahli genetika Sewall Wright (Joreskog \& Sorbom, 1996). Adapun model Path Analysis dalam penelitian ini adalah :

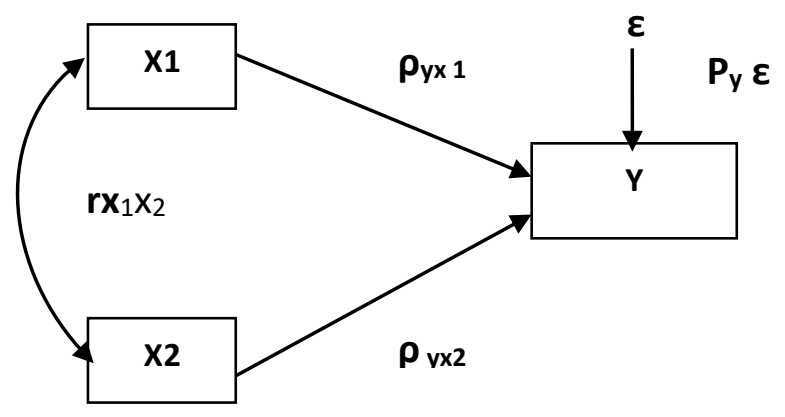

Gambar . 4

Jenis Umum Model Path Analysis

Sumber : Riduan (2012:3 )

10.

Jurnal Manajemn \& Bisnis Kreatif 


\section{HIPOTESIS}

Pengujian hipotesis adalah sebagai berikut:

1. Korelasi antara $\mathrm{X} 1$ dan $\mathrm{X} 2$ ( Uji t )

Ho : $\rho \times 2 \times 1=0 ; H 1: \rho \times 2 \times 1 \neq 0$

( terdapat korelasi antara X1 dan X2 )

$t=\frac{r \sqrt{n-2}}{\sqrt{1-r^{2}}}$ dengan $\mathrm{dk}=\mathrm{n}-2$

2. Pengaruh Parsial dari $\mathrm{X} 1$ dan $\mathrm{X} 2$ terhadap $\mathrm{Y}$ ( Uji t )

Ho : $\rho y x 1, \rho y x 2=0 ; \mathrm{H} 1: \rho y x 1, \rho y x 2 \neq 0$

( terdapat pengaruh parsial dari X1 dan X2 terhadap $\mathrm{Y}$ )

$$
t 1=\frac{\text { Prx1 }}{\sqrt{\frac{\left(1-R^{2} r(x 1 \ldots x 2) C R 11\right.}{n-k-1}}}
$$

3. Pengaruh Simultan dari X1 dan X2 terhadap Y ( Uji F )

Ho : $\rho y x 1, \rho y x 2, \rho y x 2 x 1=0 ; \quad H 1: \rho y x 1, \rho y x 2, \rho y x 2 x 1 \neq 0$

( terdapat pengaruh simultan dari $\mathrm{X} 1$ dan $\mathrm{X} 2$ terhadap $\mathrm{Y}$ )

$$
F=\frac{(n-k-1) R^{2} Y(X 1, X 2 \ldots X k)}{k\left(1-R^{2} Y(X 1, X 2 \ldots X k)\right)}
$$

\section{PEMBAHASAN}

\section{A. Deskripsi Analisis Variabel Penelitian}

\section{Deskripsi Varibael Disiplin Kerja $\left(\mathrm{X}_{1}\right)$}

Disiplin kerja, diukur melalui indikator-indikator, dengan hasil pada tabel berikut :

Tabel . 7

Rekapitulasi Tanggapan Responden

Terhadap Indikator Dimensi Disiplin Kerja

\begin{tabular}{l|c|c|c|c|c|c|c|c}
$\begin{array}{c}\text { Item } \\
\text { Pertanyaan }\end{array}$ & SS & S & CS & TS & STS & Skor & Skor Ideal & $\%$ \\
\hline Tujuan & 2 & 9 & 23 & 3 & 7 & 128 & 220 & 58,18 \\
\hline Kemampuan & 2 & 15 & 20 & 6 & 1 & 143 & 220 & 65,00 \\
\hline Sikap & 18 & 13 & 11 & 1 & 1 & 178 & 220 & 80,90 \\
\hline Perbuatan & 5 & 17 & 14 & 8 & 2 & 153 & 220 & 69,55 \\
\hline Kompensasi & 0 & 13 & 19 & 9 & 3 & 130 & 220 & 59,09 \\
\hline Welfare & 6 & 12 & 15 & 7 & 4 & 141 & 220 & 64,09 \\
\hline Perlakuan & 5 & 8 & 17 & 9 & 5 & 134 & 220 & 60,91
\end{tabular}

11. 


\begin{tabular}{l|c|c|c|c|c|c|c|c} 
Hukum & 3 & 11 & 14 & 12 & 4 & 129 & 220 & 58,64 \\
\hline Arahan & 7 & 13 & 13 & 6 & 3 & 141 & 220 & 64,10 \\
\hline Perhatian & 4 & 23 & 12 & 4 & 1 & 157 & 220 & 71,37 \\
\hline SanksiPositif & 20 & 11 & 8 & 3 & 2 & 176 & 220 & 80,00 \\
\hline Saksi negatif & 16 & 15 & 6 & 5 & 2 & 170 & 220 & 77,27 \\
\hline Konsistensi & 16 & 15 & 7 & 3 & 3 & 171 & 220 & 77,72 \\
\hline Hub. vertikal & 13 & 15 & 7 & 6 & 3 & 176 & 220 & 80,00 \\
\hline HubHerizont & 8 & 17 & 11 & 6 & 2 & 155 & 220 & 70,45 \\
\hline Jumlah & 125 & 207 & 197 & 88 & 43 & & & \\
\hline Total Skor & 625 & 828 & 591 & 176 & 43 & 2282 & 3300 & 69,15
\end{tabular}

Sumber: Hasil Pengolahan Data, 2016

Pengkategorian dilakukan berdasarkan interval batasan dengan cara : Nilai indeks min. $=1$ × 15 × $44=660$; Nilai indeks maks. $=5$ × 15 × $44=3300 ;$ Interval $=3300-660=$ 2640; Jarak interval $=2640: 5=528$

Berdasarkan tanggapan responden terhadap indicator dimensi Disiplin Kerja, memperoleh skor 2282 atau 69,15 \% dari skor 3300 dan termasuk pada kriteria "setuju" berada pada interval antara 2244 dan 2772, ditunjukkan garis kontinum sebagai berikut :

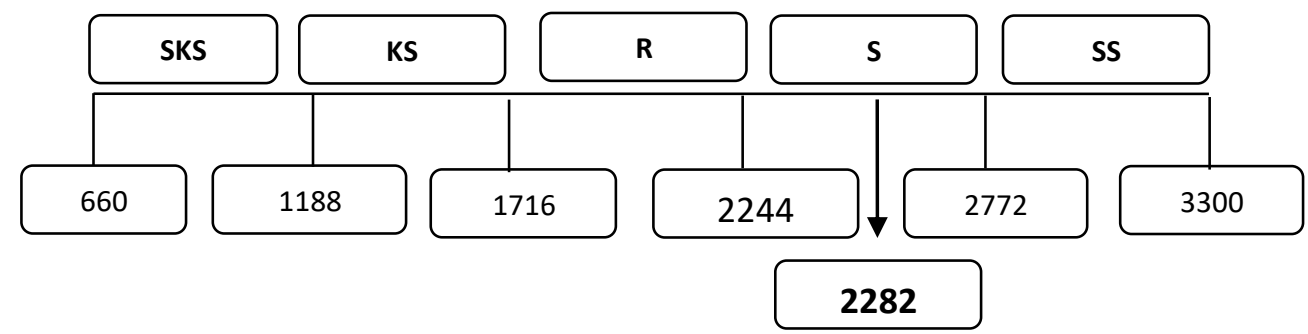

Gambar. 5

Rentang Skala Indikator Disiplin Kerja Pegawai

Bidang Tata Ruang dan Pemukiman pada Dinas Cipta Karya Kabupaten Karawang.

\section{Deskripsi Varibael Motivasi Kerja $\left(\mathrm{X}_{2}\right)$}

Motivasi kerja, diukur melalui indikator-indikator, dengan hasil pada tabel berikut :

Tabel . 8

Rekapitulasi Tanggapan Responden

Terhadap Indikator Dimensi Motivasi Kerja

\begin{tabular}{l|c|c|c|c|c|c|c|c}
$\begin{array}{c}\text { Item } \\
\text { Pertanyaan }\end{array}$ & SS & S & CS & TS & STS & Skor & $\begin{array}{c}\text { Skor } \\
\text { Ideal }\end{array}$ & $\%$ \\
\hline Nyaman & 4 & 13 & 18 & 7 & 2 & 135 & 220 & 61,36 \\
\hline Welfare & 7 & 10 & 15 & 10 & 2 & 142 & 220 & 64,55 \\
\hline Karir & 5 & 16 & 13 & 8 & 2 & 146 & 220 & 66,36 \\
\hline Kepuasan & 6 & 12 & 14 & 8 & 4 & 140 & 220 & 63,64 \\
\hline Pengakuan & 7 & 15 & 12 & 8 & 2 & 149 & 220 & 67,73
\end{tabular}

12. 


\begin{tabular}{l|c|c|c|c|c|c|c|c} 
Keterlibatan & 5 & 13 & 19 & 5 & 2 & 146 & 220 & 66,36 \\
\hline Keselamatan & 7 & 12 & 15 & 7 & 3 & 145 & 220 & 65,91 \\
\hline Kesehatan & 6 & 17 & 15 & 4 & 2 & 153 & 220 & 69,55 \\
\hline Sarana & 7 & 16 & 13 & 6 & 2 & 152 & 220 & 69,10 \\
\hline Prasarana & 7 & 13 & 16 & 6 & 2 & 149 & 220 & 67,73 \\
\hline Struktural & 9 & 11 & 13 & 10 & 1 & 149 & 220 & 67,73 \\
\hline Fungsional & 4 & 16 & 17 & 5 & 2 & 147 & 220 & 66,82 \\
\hline Dihargai & 9 & 12 & 13 & 6 & 4 & 147 & 220 & 66,82 \\
\hline Reward & 7 & 16 & 13 & 7 & 1 & 153 & 220 & 69,55 \\
\hline Punishment & 7 & 11 & 15 & 9 & 2 & 144 & 220 & 65,45 \\
\hline JUMLAH & 97 & 203 & 221 & 106 & 33 & & & \\
\hline $\begin{array}{l}\text { TOTAL } \\
\text { SKOR }\end{array}$ & 485 & 812 & 663 & 212 & 33 & 2205 & 3300 & 66,82
\end{tabular}

Sumber: Hasil Pengolahan Data, 2016

Melalui pengkategorian, dilakukan berdasarkan interval batasan dengan cara : Nilai indeks min. $=1 \times 15 \times 44=660$; Nilai indeks maks. $=5 \times 15 \times 44=3300$; Interval $=3300$ $-660=2640 ;$ Jarak interval $=2640: 5=528$

Berdasarkan tanggapan responden terhadap indicator dimensi Motivasi Kerja, memperoleh skor 2205 atau 66,82 \% dari skor 3300 dan termasuk pada kriteria "cukup setuju" berada pada interval 1716 dan 2244, ditunjukkan garis kontinum sebagai berikut :

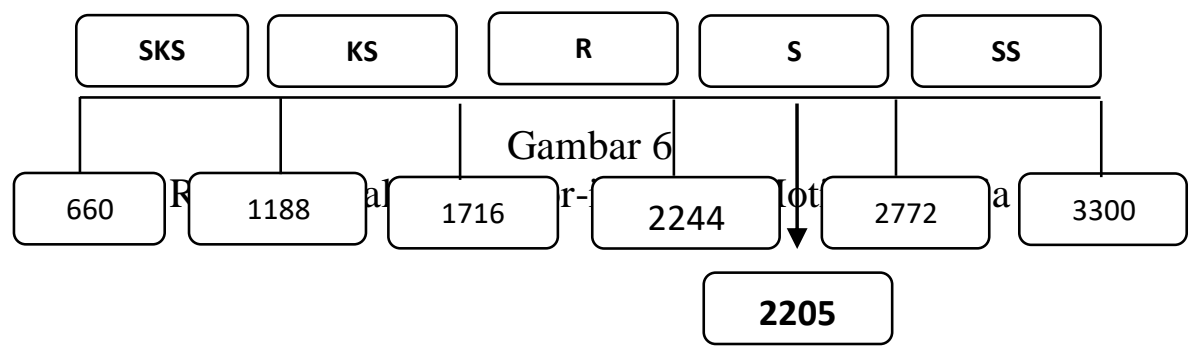

Pegawai Bidang Tata Ruang dan Pemukiman pada Dinas Cipta Karya

\section{Deskripsi Varibael Kinerja (Y)}

$$
\text { Kabupaten Karawang. }
$$

Kinerja, diukur melalui indikator-indikator, dengan hasil pada tabel berikut :

Tabel . 9

Rekapitulasi Tanggapan Responden Terhadap Indikator Dimensi Kinerja Pegawai

\begin{tabular}{l|c|c|c|c|c|c|c|c} 
Item Pertanyaan & SS & S & CS & TS & STS & Skor & $\begin{array}{c}\text { Skor } \\
\text { Ideal }\end{array}$ & $\%$ \\
\hline Kualitas & 7 & 14 & 12 & 9 & 2 & 147 & 220 & 66,82 \\
\hline Kuantitas & 7 & 16 & 11 & 10 & 0 & 152 & 220 & 69,09 \\
\hline Sasaran & 7 & 20 & 9 & 5 & 3 & 155 & 220 & 70,45 \\
\hline Waktu & 10 & 12 & 13 & 8 & 1 & 154 & 220 & 70,00 \\
\hline Guna & 7 & 20 & 9 & 5 & 3 & 155 & 220 & 70,45 \\
\hline
\end{tabular}

13. 


\begin{tabular}{l|c|c|c|c|c|c|c|c} 
Semangat & 8 & 18 & 10 & 5 & 3 & 155 & 220 & 70,45 \\
\hline Interaksi & 8 & 17 & 12 & 5 & 2 & 156 & 220 & 70,91 \\
\hline Kerjasama & 7 & 20 & 11 & 4 & 2 & 158 & 220 & 71,82 \\
\hline Beradaptasi & 7 & 20 & 9 & 5 & 3 & 155 & 220 & 70,45 \\
\hline Masalah & 10 & 13 & 12 & 7 & 2 & 154 & 220 & 70,00 \\
\hline Kehadiran & 7 & 16 & 11 & 10 & 0 & 152 & 220 & 69,09 \\
\hline Ilmu & 7 & 16 & 12 & 7 & 2 & 151 & 220 & 68,64 \\
\hline Terampil & 12 & 12 & 12 & 7 & 1 & 159 & 220 & 72,27 \\
\hline Moral & 7 & 20 & 9 & 5 & 3 & 155 & 220 & 70,45 \\
\hline Disiplin & 8 & 15 & 11 & 10 & 0 & 153 & 220 & 69,55 \\
\hline JUMLAH & 119 & 249 & 163 & 102 & 27 & & & \\
\hline TOTAL SKOR & 595 & 996 & 489 & 204 & 27 & 2311 & 3300 & 70,04
\end{tabular}

Sumber: Hasil Pengolahan Data, 2016

Melalui pengkategorian, dilakukan berdasarkan interval batasan dengan cara :

Nilai indeks min. $=1 \times 15 \times 44=660$; Nilai indeks maks. $=5 \times 15 \times 44=3300$; Interval = $3300-660=2640 ;$ Jarak interval $=2640: 5=528$

Berdasarkan tanggapan responden terhadap indicator dimensi Motivasi Kerja, memperoleh skor 2311 atau 70,04 \% dari skor 3300 dan termasuk pada kriteria "setuju" berada pada interval antara 2244 dan 2772, ditunjukkan garis kontinum sebagai berikut :

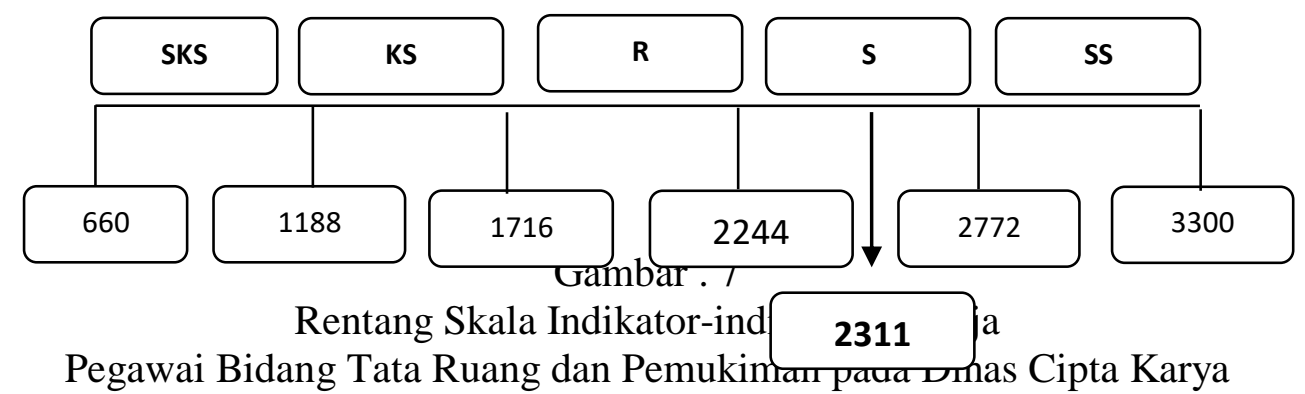

\section{B. Analisis Verifikatif}

Kabupaten Karawang.

\section{Analisis Korelasi Variabel Bebas}

Dalam analisis jalur, keterkaitan antara variabel bebas yang mempunyai hubungan berarti dapat dihitung besaran pengaruh langsung maupun pengaruh tidak langsung. Sedangkan untuk pengaruh tidak langsung dapat dihitung dengan melalui perkalian antara koefisiensi jalur dengan koefisiensi korelasinya.

Oleh karena itu terlebih dahulu dihitung masing - masing besaran koefisiensi korelasi diantara variabel bebas tersebut.

Berdasarkan hasil output SPSS hubungan kedua variabel bebas dapat dijelaskan sesuai tabel korelasi di bawah ini

14. 
Tabel . 10

Korelasi Variabel Bebas

\begin{tabular}{|c|c|c|c|c|}
\hline \multicolumn{5}{|c|}{ Correlations } \\
\hline & & Disiplin Kerja & Motivasi & Kerja \\
\hline \multirow[t]{3}{*}{ Disiplin Kerja } & Pearson Correlation & 1 & & $.614 * *$ \\
\hline & Sig. (2-tailed) & & & .000 \\
\hline & $\mathrm{N}$ & 44 & & 44 \\
\hline \multirow[t]{3}{*}{ Motivasi Kerja } & Pearson Correlation & $.614 * *$ & & 1 \\
\hline & Sig. (2-tailed) & .000 & & \\
\hline & $\mathrm{N}$ & 44 & & 44 \\
\hline
\end{tabular}

Sumber : Hasil Pengolahan Data, 2016

Hubungan antara kedua variabel bebas( Disiplin Kerja dan Motivasi Kerja ) dapat dijelaskan pada gambar di bawah ini :

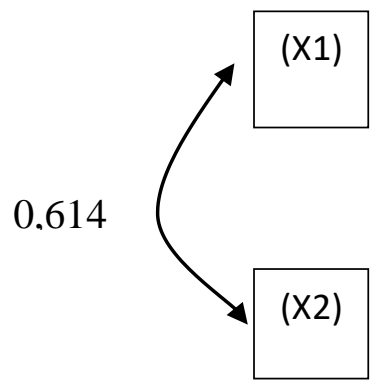

Gambar . 8

Hubungan antara Disiplin Kerja $\left(\mathrm{X}_{1}\right)$ dengan Motivasi Kerja $\left(\mathrm{X}_{2}\right)$

Sumber : Hasil Pengolahan Data, 2016.

Berdasarkan hasil analisis, besaran koefisien korelasi variabel bebas yaitu antara Variabel Disiplin Kerja (X1) dengan Motivasi Kerja (X2) di dapat nilai sebesar 0.614 yang berarti kedua variable tersebut mempunyai tingkat hubungan yang kuat dan searah karena nilainya positif.

2. Analisis Jalur ( Path Anaysis )

Koefisien jalur Disiplin $\left(\mathrm{X}_{1}\right)$ dan Motivasi $\left(\mathrm{X}_{2}\right)$ terhadap Kinerja $(\mathrm{Y})$, adalah :

Tabel . 11

Koefisien Jalur

Coefficients $^{\mathrm{a}}$

\begin{tabular}{l|c|c|c|c} 
Model & $\begin{array}{c}\text { Unstandardized } \\
\text { Coefficients }\end{array}$ & $\begin{array}{c}\text { Standardized } \\
\text { Coefficients }\end{array}$ & $\mathrm{t}$ & Sig. \\
\hline
\end{tabular}

15. 


\begin{tabular}{|c|c|c|c|c|c|c|}
\hline & & B & Std. Error & Beta & & \\
\hline \multirow[t]{3}{*}{1} & (Constant) & 61.926 & 13.012 & & 4.759 & .000 \\
\hline & Disiplin Kerja & .354 & .194 & .423 & 3.794 & .000 \\
\hline & $\begin{array}{l}\text { Motivasi } \\
\text { Kerja }\end{array}$ & .229 & .166 & .327 & 2.477 & .000 \\
\hline
\end{tabular}

a. Dependent Variable: Kinerja

Sumber: Hasil Pengolahan Data, 2016

Nilai koefisien jalur dijelaskan sebagai berikut:

a. Koefisien jalur Disiplin $\left(\mathbf{X}_{1}\right)$ terhadap Kinerja $(\mathbf{Y})=0,423$, artinya pengaruh langsung Disiplin $\left(\mathrm{X}_{1}\right)$ terhadap Kinerja $(\mathrm{Y})=0,423$, persamaannya : $\mathbf{Y}=\mathbf{0 , 4 2 3} \mathbf{X}_{\mathbf{1}}$. Pengaruh langsung variabel $\mathrm{X}_{1}$ terhadap variabel $\mathrm{Y}$ dapat digambarkan :

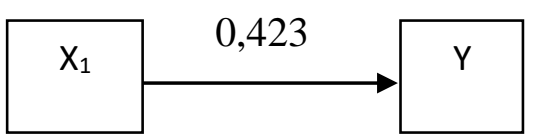

Gambar . 9

Koefisien Jalur Disiplin Kerja $\left(\mathrm{X}_{1}\right)$ terhadap Kinerja $(\mathrm{Y})$

b. Koefisien jalur Motivasi Kerja $\left(\mathbf{X}_{2}\right)$ terhadap Kinerja $(\mathbf{Y})$ : Koefisien jalur Motivasi $\left(\mathrm{X}_{2}\right)$ terhadap Kinerja (Y) adalah 0,327. Hal ini menunjukkan bahwa pengaruh langsung variabel Motivasi Kerja $\left(\mathrm{X}_{2}\right)$ terhadap variabel Kinerja $(\mathrm{Y})$ sebesar 0,327 sehingga diperoleh persamaan $\mathbf{Y}=\mathbf{0 , 3 2 7} \mathbf{X}_{2}$.

Pengaruh langsung variabel $\mathrm{X}_{2}$ terhadap variahel $\mathrm{Y}$ dapat digambarkan :

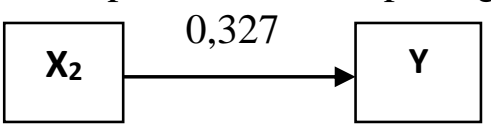

Gambar 10

Koefisien Jalur Motivasi Kerja $\left(\mathrm{X}_{2}\right)$ terhadap Kinerja (Y)

\section{c. Koefisien Jalur $X_{1}$ dan $X_{2}$ terhadap $Y$ :}

Koefisien jalur variabel $\mathrm{X}_{1}$ dan $\mathrm{X}_{2}$ terhadap $\mathrm{Y}$ dapat digambarkan di bawah ini :

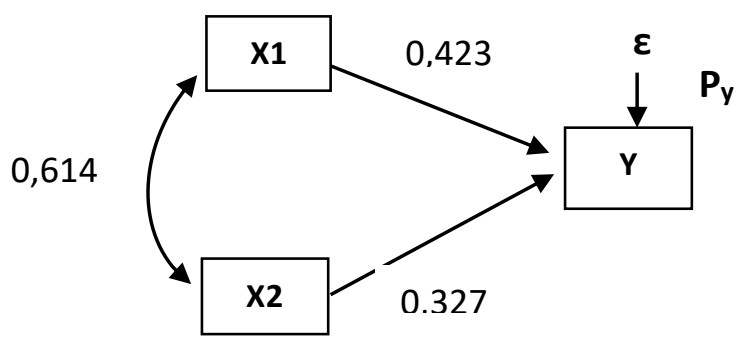

Gambar. 11

Koefisien Jalur Variabel X1 dan X2 terhadap Variabel Y

Koefisien jalur Disiplin $(0,423)$ lebih tinggi dari Motivasi $(0,327)$, artinya Disiplin $\left(\mathrm{X}_{1}\right)$ lebih berpengaruh terhadap Kinerja (Y). Persamaan: $\mathbf{Y}=\mathbf{0 , 4 2 3} \mathrm{X}_{\mathbf{1}}+\mathbf{0 , 3 2 7} \mathbf{X}_{\mathbf{2}}+\boldsymbol{\rho y \varepsilon} \mathbf{1}$

\section{Perhitungan Koefisien Determinasi (CD)}




\section{a. Pengaruh $\mathrm{X}_{1}$ terhadap $\mathrm{Y}$ :}

Pengaruh Disiplin Kerja $\left(\mathrm{X}_{1}\right)$ terhadap Kinerja $(\mathrm{Y})$ adalah :

Tabel . 12

Pengaruh Disiplin Kerja $\left(\mathrm{X}_{1}\right)$ terhadap Kinerja $(\mathrm{Y})$

\begin{tabular}{c|l|l|c} 
Variabel & \multicolumn{1}{|c|}{$\begin{array}{c}\text { Interprestasi } \\
\text { Analisis Jalur }\end{array}$} & \multicolumn{1}{|c}{ Perhitungan } & $\begin{array}{c}\text { Besarnya } \\
\text { Pengaruh }\end{array}$ \\
\hline $\mathrm{x}_{1}$ & $\begin{array}{l}\text { Pengaruh } \\
\text { Langsung Ke Y }\end{array}$ & $0,423^{2}$ & 0,179 \\
\hline & $\begin{array}{l}\text { Pengaruh Tidak } \\
\text { Langsung } \mathrm{X}_{2} \mathrm{ke} \mathrm{Y}\end{array}$ & $\begin{array}{l}0,423 \times 0,614 \mathrm{x} \\
0,327\end{array}$ & 0,085 \\
\hline & Jumlah & & 0,264
\end{tabular}

Sumber: Hasil Pengolahan Data, 2016

Pengaruh Disiplin Kerja $\left(\mathrm{X}_{1}\right)$ terhadap Kinerja (Y) sebesar 0,264 atau 26,4\%.

b. Pengaruh $\mathrm{X}_{2}$ terhadap terhadap $\mathrm{Y}$ :

Pengaruh Motivasi Kerja $\left(\mathrm{X}_{2}\right)$ terhadap Kinerja (Y) dapat dilihat tabel berikut ini.

Tabel . 13

Pengaruh Motivasi Kerja $\left(\mathrm{X}_{2}\right)$ terhadap Kinerja $(\mathrm{Y})$

\begin{tabular}{c|l|l|c} 
Variabel & \multicolumn{1}{|c|}{ Interprestasi Analisis Jalur } & \multicolumn{1}{|c}{ Perhitungan } & $\begin{array}{c}\text { Besarnya } \\
\text { Pengaruh }\end{array}$ \\
\hline $\mathrm{X}_{2}$ & Pengaruh langsung ke Y & $0,327^{2}$ & 0.107 \\
\hline & Pengaruh tidak langsung $\mathrm{X}_{2}$ ke Y & $\begin{array}{l}0,423 \times 0,614 \\
\mathrm{x} 0,327\end{array}$ & 0.104 \\
\hline \multicolumn{2}{c}{ Jumlah }
\end{tabular}

Sumber : Hasil Pengolahan Data, 2016

Pangaruh Motivasi Kerja $\left(\mathrm{X}_{2}\right)$ terhadap Kinerja (Y) sebesar 0,211 atau 21,1\%.

c. Pengaruh $X_{1}$ dan $X_{2}$ terhadap $Y$ :

Analisis manual pengaruh Disiplin $\left(\mathrm{X}_{1}\right)$ dan Motivasi $\left(\mathrm{X}_{2}\right)$ terhadap Kinerja $(\mathrm{Y})$ :

Tabel . 14

Pengaruh Didiplin Kerja $\left(\mathrm{X}_{1}\right)$ dan Motivasi Kerja $\left(\mathrm{X}_{2}\right)$ terhadap Kinerja $(\mathrm{Y})$

\begin{tabular}{|c|c|c|c|c|c|}
\hline \multirow[t]{2}{*}{ Variabel } & \multirow{2}{*}{$\begin{array}{c}\text { Koefisien } \\
\text { Jalur }\end{array}$} & \multirow{2}{*}{$\begin{array}{l}\text { Pengaruh } \\
\text { Langsung }\end{array}$} & \multicolumn{2}{|c|}{$\begin{array}{l}\text { Pengaruh Tidak } \\
\text { Langsung }\end{array}$} & \multirow{2}{*}{$\begin{array}{l}\text { Subtotal } \\
\text { Pengaruh }\end{array}$} \\
\hline & & & $\mathrm{X}_{1}$ & $\mathrm{X}_{2}$ & \\
\hline$X_{1}$ & 0,423 & 0.179 & & 0.104 & 0.264 \\
\hline $\mathrm{X}_{2}$ & 0,327 & 0.107 & 0.104 & & 0.211 \\
\hline
\end{tabular}

Sumber: Hasil Pengolahan Data, 2016

Hasil analisis menggunakan SPSS adalah :

Tabel . 15

Model Summary

\begin{tabular}{|c|c|c|c|c|}
\hline Model & $\mathrm{R}$ & R Square & $\begin{array}{l}\text { Adjusted R } \\
\text { Square }\end{array}$ & $\begin{array}{l}\text { Std. Error of the } \\
\text { Estimate }\end{array}$ \\
\hline 1 & $.708^{a}$ & .475 & .495 & 4.14485 \\
\hline
\end{tabular}

a. Predictors: Didiplin Kerja, Motivasi kerja

b. Dependent Variable:

ıerja 
R Square $\left(\mathrm{R}^{2}\right)$ 0,475 artinya Kinerja (Y) dipengaruhioleh Disiplin $\left(\mathrm{X}_{1}\right)$ dan Motivasi $\left(\mathrm{X}_{2}\right)$ sebesar $47,5 \%$, sisanya $52,5 \%$ dipengaruhi variabel lain $(\varepsilon)$ yang tidak diteliti.

\section{Pengujian Hipotesis}

\section{a. Pengujian Hipotesis Korelasi antara Disiplin $\left(\mathrm{X}_{1}\right)$ dengan Motivasi Kerja $\left(\mathrm{X}_{2}\right)$ :}

$$
\begin{aligned}
& t=\frac{r \sqrt{n-2}}{\sqrt{1-r^{2}}} \quad t=\frac{0,614 \sqrt{44-2}}{\sqrt{1-0,614^{2}}} \\
& t=\frac{3,979}{0,789} \quad t=5,043
\end{aligned}
$$

Selanjutnya harga $t_{\text {hitung }}$ dibandingkan dengan $t_{\text {tabel }}$, pada tingkat kesalahan $5 \%, \mathrm{db}=$ $\mathrm{n}-2=44-2=42$, diperoleh $\mathrm{t}_{\text {tabel }}=2,021$. Hasilnya, $\mathrm{t}_{\text {hitung }}(5,043)>\mathrm{t}_{\text {tabel }}(2,021)$, maka dapat dinyatakan bahwa $\mathrm{H}_{0}$ ditolak, artinya ada hubungan yang signifikan antara Disiplin Kerja $\left(\mathrm{X}_{1}\right)$ dengan Motivasi Kerja $\left(\mathrm{X}_{2}\right)$.

\section{b. Pengujian Hipotesis Pengaruh Parsial Disiplin $\left(\mathrm{X}_{1}\right)$ terhadap Kinerja $(\mathrm{Y})$ :}

Hipotesis pengaruh parsial Disiplin Kerja $\left(\mathrm{X}_{1}\right)$ terhadap Kinerja $(\mathrm{Y})$, dapat diketahui melalui pengujian statistik hipotesis berikut:

$\mathrm{H}_{0}$ : $\rho \mathrm{yx}_{1}=0, \mathrm{H}_{0}$ diterima : “ Tidak terdapat pengaruh Disiplin Kerja terhadap Kinerja “ $\mathrm{H}_{1}$ : $\rho \mathrm{yx}_{1} \neq 0, \mathrm{H}_{0}$ ditolak : “ Terdapat pengaruh Disiplin Kerja terhadap Kinerja “.

Kriteria Uji $=$ Tolak $\mathrm{H}_{0}$ jika Sig. $\left\langle\alpha\right.$ atau $t_{\text {hitung }}>t_{\text {tabel }}$. Dengan tingkat signifikan $(\alpha)$ $=5 \%$, degree offreedom $(\mathrm{df})=\mathrm{n}-2=44-2=42$ diperoleh $t_{\text {tabel }}=2,021$.

Berdasarkan tabel 11 di atas, thitung $=3,794$ dan Sig. 0,000, maka pengaruh $\mathrm{X}_{1}$ secara parsial terhadap Y diperlihatkan pada tabel di bawah ini :

Tabel . 16

\begin{tabular}{|c|c|c|c|c|c|}
\hline Struktur & Sig. & A & $t_{\text {hitung }}$ & $\mathrm{t}_{\text {tabel }}$ & Kesimpulan \\
\hline$\rho \mathrm{yx}_{1}$ & 0,000 & 0,05 & 3,794 & 2,021 & $\mathrm{H}_{0}$ ditolak \\
\hline
\end{tabular}

Pengaruh Parsial Disiplin $\left(\mathrm{X}_{1}\right)$ terhadap Kinerja (Y)

Pada tabel 16 bahwa Sig. $(0,000)<\alpha(0,05)$ dan $t_{\text {hitung }}(3,794)>t_{\text {tabel }}(2,021)$, maka $\mathrm{H}_{0}$ ditolak, dapat disimpulkan Disiplin Kerja berpengaruh secara parsial terhadap Kinerja.

\section{c. Hipotesis Pengaruh secara parsial Motivasi kerja $\left(\mathbf{X}_{2}\right)$ terhadap Kinerja $(\mathbf{Y})$ :}

Pengujian statistik dengan hipotesis :

$\mathrm{H}_{0}: \rho \mathrm{yx}_{2}=0$ Tidak terdapat pengaruh Motivasi kerja terhadap Kinerja

$\mathrm{H}_{1}: \rho \mathrm{yx}_{2} \neq 0 \quad$ Terdapat pengaruh Motivasi kerja terhadap Kinerja

Kriteria $=$ Tolak $\mathrm{H}_{0}$ jika Sig. $<\alpha$ atau $t_{\text {hitung }}>t_{\text {tabel }}$

18. 
Dengan signifikan $(\alpha)=5 \%$, degree of freedom $(\mathrm{df})=\mathrm{n}-2=44-2=42$ diperoleh $t_{\text {tabel }}=2,021$. Berdasarkan tabel 11, menunjukan bahwa $t_{\text {hitung }}=2,477$ dan Sig. 0,000, pengaruh $\mathrm{X}_{2}$ secara parsial terhadap $\mathrm{Y}$ seperti tabel berikut :

\section{Tabel .17}

Pengaruh Parsial Motivasi $\left(\mathrm{X}_{2}\right)$ terhadap Kinerja $(\mathrm{Y})$

\begin{tabular}{|c|c|c|c|c|c|}
\hline Struktur & Sig. & $\alpha$ & thitung & $\mathrm{t}_{\text {tabel }}$ & Kesimpulan \\
\hline & 0,00 & 0,05 & 2,477 & 2,021 & $\mathrm{H}_{0}$ ditolak \\
\hline
\end{tabular}

Sumber: Hasil Pengolahan Data ,2016

Tabel 17 menunjukkan bahwa Sig. $(0,000)<\alpha(0,05)$ dan $t_{\text {hitung }}(2,477)>t_{\text {tabel }}(2,021)$, maka $\mathrm{H}_{0}$ ditolak, disimpulkan Motivasi berpengaruh parsial terhadap Kinerja.

\section{d. Hipotesis Pengaruh secara Simultan :}

Hipotesisis pengaruh simultan Disiplin Kerja $\left(\mathrm{X}_{1}\right)$ dan Motivasi $\left(\mathrm{X}_{2}\right)$ terhadap Kinerja (Y) :

$\mathrm{H}_{0}: \rho \mathrm{yx}_{1} \mathrm{x}_{2}=0$; Tidak terdapat pengaruh Disiplin dan Motivasi terhadap Kinerja.

$\mathrm{H}_{1}: \rho \mathrm{y}_{1} \mathrm{x}_{2} \neq 0$; Terdapat pengaruh Disiplin dan Motivasi terhadap Kinerja.

Kriteria $=$ Tolak $\mathrm{H}_{0}$ jika Sig. $<\alpha$ atau $\mathrm{F}_{\text {hitung }}>\mathrm{F}_{\text {tabel }}$

Pengaruh Disiplin Kerja $\left(\mathrm{X}_{1}\right)$ dan Motivasi Kerja $\left(\mathrm{X}_{2}\right)$ secara simultan terhadap Kinerja dengan tingkat signifikan $(\alpha)=5 \%$ degree of freedom $(\mathrm{df})=\mathrm{n}-2=44-2=42$ diperoleh $\mathrm{f}_{\text {tabel }}=3,21$, dan $\mathrm{f}_{\text {hitung }}$ dapat dilihat dari table :

Tabel . 18

Hasil Perhitungan Nilai F

ANOVA $^{b}$

\begin{tabular}{|c|c|c|c|c|c|c|}
\hline Model & & $\begin{array}{l}\text { Sum of } \\
\text { Squares }\end{array}$ & df & $\begin{array}{l}\text { Mean } \\
\text { Square }\end{array}$ & $\mathrm{F}$ & Sig. \\
\hline \multirow[t]{3}{*}{1} & Regression & 83.625 & 2 & 41.812 & 15.333 & $.000^{\mathrm{a}}$ \\
\hline & Residual & 5149.352 & 41 & 125.594 & & \\
\hline & Total & 5232.977 & 43 & & & \\
\hline
\end{tabular}

a. Predictors: (Constant), MotivasiKerja, DisipliKerja

b. Dependent Variable: Kinerja

Sumber : Hasil Pengolahan Data, 2016

Berdasarkan table 18 sebagaimana di atas, bahwa $F_{\text {hitung }}=15,333$ dan Sig. $=, 000$. Pengaruh $\mathrm{X}_{1}$ dan $\mathrm{X}_{2}$ secara simultan terhadap $\mathrm{Y}$ diperlihatkan pada tabel 4.71 berikut ini:

Tabel .19

Pengaruh Simultan Disiplin Kerja $\left(\mathrm{X}_{1}\right)$ dan Motivasi Kerja $\left(\mathrm{X}_{2}\right)$

Terhadap Kinerja Pegawai (Y)

\begin{tabular}{c|c|c|c|c|c} 
Struktur & Sig. & $\alpha$ & Fhitung & $\mathrm{F}_{\text {tabel }}$ & Kesimpulan \\
\hline $\operatorname{\rho yx}_{1} \mathrm{x}_{2}$ & 0,000 & 0,05 & 15,333 & 3,21 & $\mathrm{H}_{0}$ ditolak \\
Sumber: Hasil Pengolahan Data, 2016
\end{tabular}

19.

Jurnal Manajemn \& Bisnis Kreatif 
Tabel 19 menunjukkan bahwa nilai Sig. $(0,000)<\alpha(0,05)$ dan $F_{\text {hitung }}(15,333)>F_{\text {tabel }}$ $(3,21)$, maka $\mathrm{H}_{0}$ ditolak. Maka dapat disimpulkan bahwa Disiplin Kerja dan Motivasi Kerja berpengaruh simultan terhadap Kinerja Pegawai.

\section{Pembahasan Penelitian}

1. Disipiln Kerja $\left(\mathrm{X}_{1}\right)$ berdasarkan hasil analisis indicator : tujuan pekerjaan; kemampuan kerja; sikap; perbuatan; kompensasi; kesejahteraan; kesamaan perlakuan; kesamaan hukum; arahan pimpinan; perhatian pimpinan; sanksi positif; sanksi negatif; konsistensi sanksi; hubungan vertikal; hubungan horizontal; dengan skor $2282=69,15 \%$ dari skor 3300 termasuk kriteria "setuju" pada interval 2242 dan 2772. Artinya pegawai Bidang Tata Ruang dan Pemukiman Dinas Cipta Karya Kabupaten Karawang, secara umum setuju terhadap disiplin dalam melaksanakan tugas pokok dan fungsinya

2. Motivasi Kerja (X2) berdasakan hasil analisis indicator : nyaman; kesejahteraan; pengembangan karir; kepuasan kerja; pengakuan; keterlibatan; keselamatan kerja; kesehatan kerja; sarana; prasarana; strata struktural ; strata fungsional; dihargai; reward; punishment; memperoleh skor $2205=66,82 \%$ dari skor 3300 dan termasuk pada kriteria “cukup setuju” pada interval 1716 dan 2244. Artinya pegawai Bidang Tata Ruang dan Pemukiman Dinas Cipta Karya Kabupaten Karawang, secara umum cukup setuju terhadap motivasi dalam melaksanakan tugas pokok dan fungsinya.

3. Kinerja Pegawai (Y) berdasakan hasil analisis indicator, yaitu: . kualitas; kuantitas; tepat sasaran; tepat waktu; tepat guna; semangat; berinteraksi; kerjasama; beradaptasi; pemecahan masalah; kehadiran ; pengetahuan; keterampilan; sikap moral; dan disiplin tinggi; memperoleh skor 2311 atau 70,04 \% dari skor 3300 dan termasuk pada kriteria "setuju" berada pada interval antara 2244 dan 2772. Ini artinya pegawai Bidang Tata Ruang dan Pemukiman Dinas Cipta Karya Kabupaten Karawang, secara umum setuju terhadap kinerja dalam melaksanakan tupoksinya.

4. Hubungan antara Disiplin Kerja $\left(X_{1}\right)$ dengan Motivasi Kerja $\left(X_{2}\right)$ sebesar 0,614. Ini menunjukkan atau mempunyai tingkat hubungan yang kuat dan searah karena nilainya positif, artinya apabila disiplin kerja naik maka tingkat motivasi kerja pegawai juga naik.

5. Pengaruh Parsial Disiplin Kerja $\left(\mathrm{X}_{1}\right)$ terhadap Kinerja Pegawai (Y) 0,423, maka tingkat determinasinya adalah $0,423^{2}=0,179$ atau $17,9 \%$. Ini menunjukkan bahwa pengaruh Disiplin Kerja terhadap Kinerja Pegawai adalah 17,9\%.

Sedangkan pengaruh parsial Moptivasi Kerja $\left(\mathrm{X}_{2}\right)$ terhadap Kinerja Pegawai (Y) sebesar 0,327 , maka tingkat determinasinya adalah $0,327^{2}=0.107$ atau $10,7 \%$, Ini menunjukkan bahwa pengaruh Motivasi Kerja terhadap Kinerja Pegawai adalah sebesar 10,9\%.

Oleh karena 0,423 lebih besar dari 0,327 atau persentase 17,9 \% lebih besar dari 10,9\%, maka dapat dinyatakan bahwa variabel Disiplin Kerja lebih banyak memberikan kontribusi terhadap Kinerja Pegawai jika dibandingkan variabel dengan variable Motivasi Kerja.

6. Pengaruh Disiplin Kerja $\left(\mathrm{X}_{1}\right)$ dan Motivasi Kerja $\left(\mathrm{X}_{2}\right)$ terhadap Kinerja Pegawai $(\mathrm{Y})$, dengan kriteria uji Sig. $(0,0000)>\alpha(0,05)$ dan $F_{\text {hitung }}(15,333)>F_{\text {tabel }}(3,21)$, artinya $H 0$ ditolak. Total pengaruh Disiplin Kerja $\left(\mathrm{X}_{1}\right)$ dan Disiplin Kerja $\left(\mathrm{X}_{2}\right)$ terhadap Kinerja Pegawai (Y) sebesar 0,475 atau 47,5\%. Hal ini menunjukkan bahwa Disiplin Kerja ( $\left.\mathrm{X}_{1}\right)$ dan Motivasi Kerja $\left(\mathrm{X}_{2}\right)$ pegawai pada Bidang Tata Ruang dan Pemukiman Dinas Cipta 
Karya Kabupaten Karawang memiliki kontribusi terhadap Produktivitas Kerja (Y) sebesar 47,5\%, sedangkan sisanya sebesar 52,5\% merupakan kontribusi variabel lain $(\varepsilon)$ yang tidak diteliti dalam penelitian ini.

\section{KESIMPULAN}

Berdasarkan hasil analisis dan pembahasan, maka dapat disimpulkan :

1. Disiplin Kerja $\left(\mathrm{X}_{1}\right)$ pada Bidang Tata Ruang dan Pemukiman Dinas Cipta Karya Kabupaten Karawang, dengan 15 butir pernyataan diperoleh total skor sebesar 2205 berada pada rentang skala 2244 - 2772, menunjukan para pegawai setuju mengenai Indikator yang harus dipertahankan, yaitu kategori "sangat setuju", seperti : sikap, sanksi positif, sanksi negatif, dan konsistensi sanksi. Sedangkan skor di bawah kriteria setuju harus ditingkatkan lagi.

2. Motivasi Kerja $\left(\mathrm{X}_{2}\right)$ pada Bidang Tata Ruang dan Pemukiman Dinas Cipta Karya Kabupaten Karawang, dengan 15 butir pernyataan diperoleh total skor 2265 berada pada rentang skala 1716 - 2244, menunjukan bahwa pegawai menyatakan 'cukup setuju “. Terdapat indikator harus ditingkatkan lagi, karena responden yang menyatakan cukup setuju melebihi dari sepertiga responden, sehingga perlu mendapat perhartian pimpinan.

3. Kinerja (Y) pada Bidang Tata Ruang dan Pemukiman Dinas Cipta Karya Kabupaten Karawang, dari 15 butir pernyataan diperoleh total skor 2311 pada rentang skala 2244 2772 dengan kriteria "setuju". Indikator perlu ditingkatkan : kualitas, kuantitas, selesai tepat waktu, semangat, berinteraksi, kerjasama, pemecahan masalah, kehadiran, pengetahuan, keterampilan, dan tingkat disiplin tinggi.

4. Koefisien Korelasi diantara variabel bebas antara Disiplin Kerja $\left(\mathrm{X}_{1}\right)$ dengan Motivasi $\left(\mathrm{X}_{2}\right)$ pegawai, dengan nilai 0,614 ; berarti mempunyai tingkat hubungan kuat dan searah dan pengujian hipotesis korelasi antara Disiplin Kerja $\left(\mathrm{X}_{1}\right)$ dengan Motivasi Kerja $\left(\mathrm{X}_{2}\right)$ pada tingkat kesalahan $5 \%, \mathrm{db}=\mathrm{n}-2=44-2=42$, diperoleh $\mathrm{t}_{\text {tabel }}=2,021$, maka dapat diketahui bahwa $t_{\text {hitung }}(5,043)>t_{\text {tabel }}(2,021)$, maka dapat dinyatakan bahwa $\mathrm{H}_{0}$ ditolak, artinya terdapat hubungan yang signifikan antara Disiplin Kerja $\left(\mathrm{X}_{1}\right)$ dengan Motivasi Kerja $\left(\mathrm{X}_{2}\right)$ yang kuat pada pegawai Bidang Tata Ruang dan Pemukiman Dinas Cipta Karya Kabupaten Karawang.

5. Koefisien Jalur Variabel Disiplin Kerja $\left(\mathrm{X}_{1}\right)$ secara parsial terhadap Kinerja (Y) sebesar 0,431, Sehingga persamaannya $\mathrm{Y}=0,431 \mathrm{X}_{1}$ dan Untuk Hipotesis Disiplin Kerja $\left(\mathrm{X}_{1}\right)$ secara parsial terhadap Produktivitas $\operatorname{Kerja}(Y)$ dengan tingkat signifikan $(\alpha)=5 \%$, degree of freedom $(\mathrm{df})=\mathrm{n}-2=139-2=137$ diperoleh $\mathrm{t}_{\text {tabel }}=1,960$. Menunjukan bahwa $t_{\text {hitung }}=4,821$ dan Sig. $(0,000)<\alpha(0,05)$ dan $t_{\text {hitung }}(4,821)>t_{\text {tabel }}(1,960)$, maka $\mathrm{H}_{0}$ ditolak, dapat disimpulkan Disiplin Kerja berpengaruh parsial terhadap Kinerja.

6. Koefisien Jalur Variabel Motivasi $\left(\mathrm{X}_{2}\right)$ secara parsial terhadap Variabel Kinerja adalah sebesar 0,328 sehingga persamaannya $\mathrm{Y}=0,328 \mathrm{X}_{2}$ dan Untuk Hipotesis Motivasi $\left(\mathrm{X}_{2}\right)$ secara parsial terhadap Kinerja $(Y)$ dengan tingkat signifikan $(\alpha)=5 \%$, degree of freedom $(\mathrm{df})=\mathrm{n}-2=139-2=137$ diperoleh $\mathrm{t}_{\text {tabel }}=1,960$. Hal ini menunjukkan bahwa Sig. $(0,000)<\alpha(0,05)$ dan $t_{\text {hitung }}(3,673)>t_{\text {tabel }}(1,960)$, maka $\mathrm{H}_{0}$ ditolak. Dengan demikian dapat disimpulkan bahwa Motivasi berpengaruh parsial terhadap Kinerja

7. Koefisien Jalur Variabel Disiplin Kerja $(0,431)$ lebih tinggi dibandingkan dengan Variabel Motivasi $(0,328)$, artinya Disiplin Kerja $\left(\mathrm{X}_{1}\right)$ lebih berpengaruh terhadap Kinerja (Y) 
dibandingkan dengan Motivasi $\left(\mathrm{X}_{2}\right)$. Dan Untuk Hipotesis Variabel Disiplin Kerja $\left(\mathrm{X}_{1}\right)$ dan Motivasi $\left(\mathrm{X}_{2}\right)$ secara simultan mempunyai pengaruh yang positif dan signifikan terhadap Kinerja pada Bidang Tata Ruang dan Pemukiman Dinas Cipta Karya Kabupaten Karawang. Hal ini telah dibuktikan melalui uji F, di mana hasil uji F memperlihatkan bahwa Untuk Disiplin Kerja $\left(\mathrm{X}_{1}\right)$ dan Motivasi $\left(\mathrm{X}_{2}\right)$ secara simultan terhadap Kinerja dengan tingkat signifikan $(\alpha)=5 \% \quad(\mathrm{df})=\mathrm{n}-2=139-2=137$ menunjukkan bahwa nilai Sig. $(0,000)<\alpha(0,05)$ dan $\mathrm{f}_{\text {hitung }}(68,513)>\mathrm{f}_{\text {tabel }}(3,02)$, maka $\mathrm{H}_{0}$ ditolak. Total pengaruh Disiplin Kerja $\left(\mathrm{X}_{1}\right)$ dan Motivasi $\left(\mathrm{X}_{2}\right)$ terhadap Kinerja $(\mathrm{Y})$ sebesar 0,502 atau $50,2 \%$. Hal ini menunjukkan bahwa Disiplin Kerja $\left(\mathrm{X}_{1}\right)$ dan Motivasi $\left(\mathrm{X}_{2}\right)$ memiliki kontribusi terhadap Kinerja (Y) sebesar 50,2\%, sisanya 49,8\% merupakan kontribusi variabel lain $(\varepsilon)$ yang tidak diteliti, artinya peneliti berikutnya dapat memilih variable lainnya.

\section{DAFTAR PUSTAKA}

Arikunto, Suharsimi.1996. Prosedur Penelitian Suatu Pendekatan Praktis, Jakarta: Bina Aksara.

Davis, Keith dan Newstrom, John W.1985. Human Bahavior at Work: Organizational Behavior. McGraw-Hill, Inc.

Dwiyanto, Agus.1995. Penilaian Kinerja Organisasi Pelayanan Publik, Yogyakarta: Fisipol Universitas Gajah Mada.

Fathoni, 2004. Organisasi dan manajemen sumber daya manusia, Jakarta:_Mahastya.

Juni Priansa, Donni. 2007. Perencanaan \& Pengembangan SDM, Bandung: Prisma pustaka.

Gibson, James L; John M. Ivancevich; dan James H. Donnelly. 1997 Organisasi dan Manajemen: Perilaku, Struktur, Proses, terjemahan Djoebran W., Jakarta: Erlangga.

Hadi, Sutrisno.1978 Metodologi Research, Yogyakarta: Yayasan Penerbit Fakultas Psikologi Universitas Gadjah Mada.

Hasibuan, Malayu S.P. 2000 Manajemen Sumber Daya Manusia, Jakarta: Bumi Aksara.

Keban, Yeremias J. 1995 Analisis Peran dalam Penentuan Alternatif Kebijakan Publik, Yogyakarta: MAP-UGM.

Kumorotomo, Wahyudi. 1992 Etika Administrasi Negara, Jakarta: RajaGrafindo

Persada.

Mangkunegara, Anwar Prabu. 2000 Manajemen Sumber Daya Manusia Perusahaan, Bandung: Remaja Rosdakarya. 
Mangkunegara, Anwar Prabu. 1991 Manajemen Kepegawaian dan Sumber Daya Manusia, Bandung: IKOPIN.

Rivai, Veithzal. 2005 Manajemen Sumber Daya Manusia untuk Perusahaan: dari Teori ke Praktek, Jakarta: RajaGrafindo Persada.

Sembel, Kartini. $2002 \quad$ Tesis: “Analisis Kinerja Aparatur pada Sekretariat Daerah Propinsi Sulawesi Utara”, Yogyakarta: Program Pascasarjana Universitas Gadjah Mada.

Siagian, Sondang P. 1994 Patologi Birokrasi, Analisis, Identifikasi dan Terapinya, Jakarta: Ghalia Indonesia.

Sugiyono. $2002 \quad$ Metode Penelitian Administrasi, Bandung: Alfabeta.

Winardi. 1990 Azas Manajemen, Bandung: Mandar Maju.

Marwansyah, 2012. Manajemen Sumber Daya Manusia, Bandung, Alfabeta CV.

Nurul Zuriah. 2006. Metodologi Penelitian Sosial dan Pendidikan Teori - Aplikasi, Bumi Akasara, Jakarta.

Suwatno \& Donni Juni Priansa. 2011. Manajemen SDM dalam Organisasi Publik dan Bisnis, Alfabeta, Bandung.

Sugiyono. 2007. Metode Penelitian Administrasi, Alfabeta, Bandung

Sedarmayanti, 2011. Manajemen Sumber daya Manusia Reformasi Birokrasi dan Manajemen Pegawai negeri Sipil, Bandung, PT. Refika Aditama

Veithzal Rivai. 2005. Manajemen Sumber Daya Manusia Untuk Perusahaan dari Teori ke Praktik, PT Rajagrafindo Persada, Jakarta. 